\title{
D. D. R. WILLIAMS
}

\section{The Hay Festival: superb Continuing Medical Education}

26 May 2000-4 June 2000

Clinical governance and revalidation will further emphasise the importance of continuing medical education. In addition to the scientific advances in one's own speciality there is a need to keep up with the wider developments in the social, medical and cultural areas. This is now more important because of the expanding gulf between the miraculous progress of technology and the paradox that modern man, in anthropological terms, is functioning emotionally more at a level with new stone age man. Is there an easy way of being up-to-date with modern perspectives in the wider field of general scientific and cultural development?

Fortunately, for us in Wales, we have the opportunity of doing this by a well planned visit to the Hay Festival. This is an annual event in the early summer in the town of Hay in the delightful border county of Breconshire. Hay is a small market town of 1300 people and 36 bookshops, hence its new name 'The Book Town'. It is often referred to as the Literary Festival. However, it is a much more comprehensive event than the term literature implies. Last year, 1999, was the 10th and its formula for success is simple. Authors would like to meet their readers and the readers in turn want to engage with the author. The core activities are lectures and presentations by writers who have published a book during the previous year or two. The topics cover a wide spectrum embracing all the arts and sciences with priority given to the growing edge of each discipline. In addition, there are exhibitions, concerts and demonstrations. Visits are organised to places of interest such as the restoration work on the medieval gardens at Aberglasney. In contrast, the Brecon Beacons are at hand providing excellent hill-walking.

There is a rich scientific, medical and psychological dimension. John Maddox, the former editor of Nature, is closely linked with the festival. Last year, in addition to lectures during the whole of the festival, one day was dedicated to medical and psychological issues. Tom Kirkwood, Professor of Gerontology, outlined his theory of ageing and how we can slow it down. He gave his prediction about what the human body will be like in the year 2200. A lecture on neuroimaging considered the question of where the human personality is located in brain tissue! Another lecture focused on our understanding of consciousness while lan Robertson, Professor of Psychology at Trinity College, Dublin, outlined the brain's phenomenal reserve capacity even after substantial damage has occurred.

The Festival is an exceptional feast. To Welsh speakers it is similar to the National Eisteddfod - but without the competitions. The speakers are of international calibre and many are invited because of their exceptional ability as communicators. Steve Jones, Richard Dawkins, Roy Strong, Anthony Howard, David Crystal, Antonia Fraser and Richard Gregory are good examples. Last year Steve Jones, in his Predictions Lecture, argued that human evolution has stopped when it comes to our bodies but probably not for our minds.

As scientific medicine continues to advance, the drift towards alternative medicine continues. It is a sign that it is essential for patients to be treated as individuals in a sophisticated holistic and empathic way. It isn't easy, and Kafka's (1961) aphorism remains true today, "prescribing is so easy, understanding people so hard". A visit to the Hay Festival would help to bolster the approach that needs to be encouraged.

This year's festival is from the 26 May-4 June. Further information can be obtained from the Festival Box Office, Hay-on-Wye, HR3 5BX; tel: 01497 821299; fax: 01497 821066; e-mail: tickets @litfest.co.uk.

\section{Reference}

KAFKA, F. (1961) A country doctor. In The Penal Colony, Stories and Short Pieces. (trans. W. Muir \& E. Muir), pp. 140. New York: Shocker Books.

D. D. R. Williams Consultant Psychiatrist, Cefn Coed Hospital, Waunarlwydd Road, Cockett, Swansea SA2 OGH 